\title{
Pengembangan Modul Litosfer untuk Meningkatkan Hasil Belajar Mata Pelajaran Geografi pada Kelas X Sekolah Menengah Atas
}

\author{
Siti Wa'dah \\ SMA Negeri 1 Gerung, Kabupaten Lombok Barat NTB \\ Corresponding Author. Email: sitiwadah55@gmail.com
}

\begin{abstract}
The purpose of this research is to develop a lithosphere module for grade X SMA / MA students using the Dicky \& Carey development model and to find out the effectiveness of the developed module. This research method uses research and development. The instruments used in this study were questionnaires and tests for each learning activity. The data analysis technique of this research uses descriptive statistical analysis. In this research, five modules have been developed, namely Module I (Structure of the Lithosphere Layer), Module 2 (Endogenous Energy), Module 3 (Exogenous Energy), Module 4 (Pedosphere), and Module 5 (Soil Erosion). Based on the results of field trials, this learning module has succeeded in showing benefits.
\end{abstract}

\begin{abstract}
Abstrak: Tujuan penelitian ini adalah untuk mengembangkan Modul Litosfer untuk siswa kelas X SMA/MA dengan menggunakan model pengembangan Dicky \& Carey dan menemukan keefektifan modul yang dikembangkan tersebut. Metode penelitian ini menggunakan penelitian dan pengembangan. Instrumen yang digunakan dalam penelitian ini adalah angket dan tes pada setiap kegiatan pembelajaran. Teknik analisis data penelitian ini menggunakan analisis statistik deskriptif. Dalam penelitian ini telah dikembangkan lima modul, yaitu Modul I (Stuktur Lapisan Litosfer), Modul 2 (Tenaga Endogen), Modul 3 (Tenaga eksogen), Modul 4 (Pedosfer), dan Modul 5 (Erosi Tanah). Berdasarkan hasil uji coba lapangan, modul pembelajaran ini telah berhasil menunjukkan kebermanfaatan.
\end{abstract}

\section{Article History}

Received: 23-11-2020

Revised: 21-12-2020

Published: 07-01-2021

\section{Key Words:}

Development, Modules, Learning Outcomes, Geography.

\section{Sejarah Artikel}

Diterima: 23-11-2020

Direvisi: $21-12-2020$

Diterbitkan: 07-01-2021

\section{Kata Kunci:}

Pengembangan, Modul, Hasil Belajar, Geografi.

How to Cite: Wa'dah, S. (2021). Pengembangan Modul Litosfer untuk Meningkatkan Hasil Belajar Mata Pelajaran Geografi pada Kelas X Sekolah Menengah Atas. Jurnal Paedagogy, 8(1). doi:https://doi.org/10.33394/jp.v8i1.3166

\section{Pendahuluan}

Upaya peningkatan mutu pendidikan terus dilakukan oleh pemerintah, di antaranya adalah dengan melakukan perluasan penyediaan fasilitas pendidikan, peningkatan kualitas tenaga pendidik, perbaikan kualitas kurikulum, dan per-luasan kesempatan untuk memperoleh pendidikan bagi semua warga negara. Dalam hal peningkatan kualitas kurikulum, sesuai dengan PP No.19 Tahun 2005 tentang Standar Nasional Pendidikan, pendidikan di Indonesia sekarang ini mengacu pada Kurikulum Tingkat Satuan Pendidikan (KTSP). Kurikulum ini merupakan perbaikan dan perluasan Kurikulum Berbasis Kompetensi (KBK). KTSP pada jenjang pendidikan dasar dan menengah dikembangkan oleh sekolah dan komite sekolah dengan berpedoman pada Standar Kompetensi Kelulusan (SKL), standar isi (SI), serta panduan penyusunan yang dibuat oleh Badan Standar Nasional Pendidikan (BSNP) (Depdiknas, 2006).

Kurikulum Tingkat Satuan Pendidikan (KTSP) dilaksanakan berdasarkan prinsip bahwa potensi, perkembangan, dan kondisi peserta didik diarahkan untuk menguasai kompetensi yang berguna bagi dirinya. Hal ini berarti bahwa peserta didik harus mendapatkan pelayanan pendidikan yang bermutu. Selain itu, peserta didik juga harus 
memperoleh kesempatan untuk mengekspresikan dirinya secara bebas, dinamis, dan menyenangkan.

Pembelajaran pada Kurikulum Tingkat Satuan Pendidikan difokuskan kepada pengembangan kemampuan siswa untuk menguasai berbagai kompetensi yang tertuang dalam standar isi. Kompetensi tersebut tidak dapat dikembangkan secara optimal jika dalam kegiatan pembelajaran, siswa tidak dilengkapi dengan buku teks yang berkualitas. Untuk mengembangkan potensi siswa dalam pembelajaran, guru dapat menggunakan bahan ajar. Bahan ajar adalah buku yang berisi bahan pelajaran suatu bidang studi tertentu yang digunakan sebagai buku acuan, baik oleh guru maupun siswa dalam kegiatan pembelajaran. Bahan ajar diperlukan guru untuk kelangsungan kegiatan pembelajaran di kelas. Bahan ajar bagi siswa diperlukan sebagai sarana untuk menimbulkan keterlibatannya dalam belajar. Oleh karena itu, keberadaan bahan ajar tidak dapat dipisahkan antara siswa dan kegiatan pembelajaran. (Hilton dalam Wahyuni, 2002) menyatakan "bila guru menggunakan bahan ajar sebagai sumber belajar dan mengajar, maka perancangan bahan ajar berpengaruh terhadap metode dan proses belajar".

Fakta di lapangan menunjukkan bahwa pada setiap mata pelajaran hampir selalu ada sumber belajar yang berupa buku teks sesuai dengan spesifikasi mata pelajaran. Dalam dunia pendidikan, khususnya sekolah, diharuskan adanya bahan ajar yang ditulis dengan konsep dan teori yang dapat mendorong siswa untuk mampu mencerna dan memahami isi bahan ajar secara maksimal. Bahan ajar tersebut merupakan pedoman teoritis utama bagi siswa dalam memahami suatu mata pelajaran, seperti halnya pada matapelajaran geografi.

Dalam bahan ajar, konsep dan bahasa merupakan komponen yang penting dalam menentukan berkualitas-tidaknya bahan ajar. Selain konsep dan bahasa yang menjadi penentu kualitas buku ajar, media gambar juga mempunyai peranan yang penting, selain untuk menarik konsumen untuk membeli buku. Fungsi utama media gambar adalah memberi penjelasan sehingga dapat meningkatkan pemahaman dan ingatan mengenai informasi yang terdapat pada bahan ajar atau buku ajar. Menurut Brody, dkk. (dalam Azwar, 1993), "gambar pada buku ajar akan berfungsi secara efektif jika gambar tersebut sesuai dengan isi materi dalam buku ajar".

Selama ini penulisan bahan ajar geografi belum mampu mendorong siswa untuk mau mendalami secara seksama keilmuan geografi. Oleh karena itu, kesadaran akan pentingnya bahan ajar dalam kegiatan pembelajaran geografi menarik untuk diteliti. Apalagi, bahan ajar akan dijadikan pegangan guru dan siswa dalam proses pembelajaran, tetapi banyak bahan ajar yang disusun guru kualitas dan kuantitasnya masih rendah.

Pembuatan bahan ajar merupakan alternatif penting sebagai pengganti buku teks yang selama ini banyak digunakan oleh guru. Sementara di sisi lain, buku teks banyak memiliki kelemahan, di antaranya ketepatan penggunaan bahasa, contoh, konsep, generalisasi, penyajian gambar, kebenaran objek material dan objek formal, serta ketercernaan materi. Dalam bahan ajar yang disusun oleh guru, masih terdapat banyak kesalahan pada komponenkomponen tersebut. Hal ini sejalan dengan hasil penelitian Sumarmi, dkk. (2001) tentang pencitraan buku teks geografi SMU, bahwa: (1) komposisi buku teks geografi SMA didominasi fakta/data, sebagian kecil konsep, dan sangat sedikit generalisasi, (2) buku teks tersebut disusun mayoritas model deduktif, (3) masih banyak gambar yang disajikan justru tidak berfungsi, (4) kesalahan paragraf dan kalimat masih banyak ditemukan, dan (5) karena komposisi fakta/data sangat mendominasi, konsep sedikit, dan generalisasi sangat sedikit yang tidak mengikuti pola piramida seperti yang dikemukakan Savage and Armstrong, maka siswa terpaksa harus banyak berhadapan dengan fakta/data yang harus dihapal, sehingga 
apabila harus mempelajari geografi melalui buku teks yang ada, maka siswa harus memiliki kekuatan menghapal fakta/data dan konsep. Di samping itu, hasil penelitian Purwanto, dkk. (1999) menunjukan bahwa "Penyusunan buku ajar, walaupun banyak sumber (kepustakaan) dan ditulis oleh ahlinya, masih banyak ditemukan kesalahan, buku ajar yang akan beredar di pasaran tidak pernah divalidasi atau dievaluasi melalui seminar, diskusi, dan sejenisnya".

Uraian dari hasil penelitian tersebut mendukung alasan dilakukannya penelitian ini, bahwa kehadiran bahan ajar yang berkualitas dirancang dengan asumsi dapat dipahami dengan baik tanpa guru sekalipun, serta relevan terhadap temuan terbaru menjadi sangat mendesak. Keberadaan bahan ajar sangat penting artinya bagi guru dan siswa dalam kegiatan pembelajaran. Bagi guru, bahan ajar merupakan sumber informasi yang dapat dijadikan pedoman mengajar yang harus ditransfer kepada siswa. Bagi siswa, bahan ajar merupakan sumber belajar yang dapat meningkatkan kemampuan siswa sehingga tujuan pembelajaran dapat tercapai. Tanpa adanya bahan ajar yang memadai, kegiatan pembelajaran tidak dapat berlangsung secara optimal.

Perlunya penyusunan bahan ajar dimaksudkan untuk dapat memperbaiki bahan ajar lain yang memiliki kekurangan. Upaya perbaikan pembelajaran dilakukan dengan memperbaiki proses yang diwujudkan dengan pengembangan bahan ajar yang lengkap. Bahan ajar yang lengkap selain dapat digunakan oleh siswa dan guru dalam pembelajaran di kelas, juga dapat digunakan secara efektif oleh siswa secara individu.

Litosfer dan pedosfer merupakan salah satu materi yang diajarkan pada matapelajaran geografi kelas X semester II. Pada materi tersebut dibahas struktur lapisan kulit bumi, macam-macam bentuk muka bumi sebagai akibat proses vulkanisme, seisme, dan diastropisme, ciri bentang alam, degradasi lahan, ciri dan proses pembentukan tanah, erosi tanah, serta usaha untuk mengurangi erosi tanah. Untuk menjelaskan topik tersebut harus diperhatikan beberapa aspek penting, diantaranya kebenaran, bahasa, fakta/data konsep, generalisasi, penyajian gambar yang tepat, kebenaran objek material dan objek formal, serta kecermatan materi yang ada dalam topik tersebut.

Berdasarkan hasil analisis yang dilakukan terhadap buku teks geografi SMA kelas X Semester II pada materi Litosfer dan Pedosfer penerbit Phibeta tahun 2006 masih ditemukan kesalahan bahasa, fakta/data, konsep, generalisasi, penyajian gambar yang tidak representatif, kesalahan penyajian objek material dan objek formal, serta kesulitan mencerna materi yang ada dalam topik tersebut.

Kesalahan yang sama dijumpai pada modul Geografi Kelas X kompetensi dasar Litosfer tulisan Sutama (2006). Modul Litosfer yang ditulis Sutama setidak-tidaknya memiliki empat kesalahan sebagai berikut. Pertama, bagian pendahuluan modul tidak memuat: (a) standar kompetensi atau kompetensi dasar, (b) deskripsi singkat mengenai modul, (c) prasyarat, (d) petunjuk penggunaan modul, (e) tujuan akhir, dan (f) cek penguasaan SK dan KD. Kedua, bagian pembelajaran sajian materi tidak sesuai dengan kompetensi dasar yang diprasyaratkan oleh BSNP 2006, antara lain: (a) kegiatan belajar 1: struktur lapisan kulit bumi (litosfer) dan bentuk muka bumi, (b) kegiatan belajar 2: perubahan bentang alam dan dampaknya terhadap kehidupan. Seharusnya berdasarkan BSNP 2006, maka kegiatan belajar diurutkan sebagai berikut: (a) kegiatan belajar 1: struktur lapisan kulit bumi, (b) kegiatan belajar 2: tenaga endogen, (c) kegiatan belajar 3: tenaga eksogen, (d) kegiatan belajar 4: pedosfer, (e) kegiatan belajar 5: proses erosi tanah. Ketiga, uraian materi masih terlalu umum dan sulit dipahami siswa, seharusnya disajikan sesuai dengan kompetensi dasar secara rinci dan mendetail agar memudahkan siswa mempelajari isi modul. Keempat, gambar yang disajikan cenderung tidak relevan dengan uraian materi, tidak berwarna dan 
tidak menarik, terlalu kecil, seperti gambar 04.02 (halaman 7), gambar 04.03 dan gambar 04.04 (halaman 8), gambar 04.17 (halaman 20), gambar 04.17 (halaman 20), demikian pula gambar-gambar lain yang ada dalam isi modul.

Salah satu alternatif untuk mengatasi permasalahan tersebut adalah merancang bahan ajar geografi dengan menggunakan model Dick \& Carey. Pengunaan model Dick \& Carey didasarkan atas pemikiran bahwa model ini menggunakan pendekatan sistem dengan langkah-langkah yang lengkap, sehingga dapat digunakan untuk mengembangkan bahan ajar. Selain itu, kesepuluh langkah yang terdapat dalam model pengembangan Dick \& Carey menunjukkan hubungan yang jelas dan tidak terputus antara langkah yang satu dengan langkah yang lainya. Dengan kata lain, sistem yang terdapat pada model Dick \& Carey sangat ringkas, namun isinya padat dan jelas.

Berkaitan dengan pengembangan bahan ajar, Dick \& Carey (2001) mengajukan halhal berikut untuk diperhatikan, yakni: (1) motivasi belajar yang diinginkan, (2) kesesuaian materi yang diberikan, (3) mengikuti suatu urutan yang benar, (4) berisikan informasi yang dibutuhkan, dan (5) adanya latihan praktik, (6) dapat memberikan umpan balik, (7) tersedia tes yang sesuai dengan materi yang diberikan, (8) tersedia petunjuk untuk tindak lanjut ataupun kemajuan umum pembelajaran (9) tersedia petunjuk bagi peserta didik untuk tahaptahap aktivitas yang dilakukan, dan (10) dapat diingat dan ditransfer.

Beberapa penelitian juga mengungkapkan keberhasilan model pe-ngembangan paket pembelajaran yang menggunakan model Dick \& Carey dalam pembelajaran. Penelitian yang dilakukan oleh Hermawan (2006) menunjukkan bahwa paket pembelajaran kimia yang dikembangkan untuk siswa kelas X SMA Negeri 1 Dolo Sulawesi Tengah efektif untuk meningkatkan hasil belajar siswa. Husain (2003) mengungkapkan bahwa pengembangan dengan mengunakan model Dick \& Carey dapat meningkatkan perolehan hasil belajar pada matapelajaran Dasar Listrik dan Elektro di SMK Muhammadiyah I Malang. Begitu pula dengan penelitian yang dilakukan oleh Junaidi (2008) yang menemukan bahwa terdapat peningkatan hasil belajar siswa ketika menggunakan bahan ajar model Dick \& Carey.

Pengembangan modul litosfer ini mengacu pada petunjuk teknis pembuatan modul oleh Depdiknas dan beberapa petunjuk teknis lainnya, seperti pedoman penyusunan modul oleh Depkes, Dephut, dan contoh modul Universitas Terbuka (UT). Beberapa acuan tersebut dipakai agar modul yang dihasilkan benar-benar memiliki kualitas, baik dari sistematika maupun isi/materi.

\section{Metode Penelitian}

Metode penelitian ini menggunakan penelitian dan pengembangan. Model pengembangan yang digunakan dalam pengembangan produk modul litosfer dan pedosfer untuk SMA/MA Kelas X Semester II adalah mengacu pada Model Dick \& Carey. Model penelitian pengembangan yang akan digunakan dalam penelitian ini termasuk dalam kategori model konseptual karena modelnya menganalisis komponen-komponen produk yang akan dikembangkan serta keterkaitan antar komponen. Penentuan model tersebut didasarkan pada pertimbangan bahwa produk yang dihasilkan merupakan pengembangan dari produk yang sudah ada sebelumnya, yaitu bahan ajar yang digunakan pada Mata pelajaran geografi buku teks geografi SMA/MA Kelas X semester II pada materi litosfer dan pedosfer penerbit Phibeta tahun 2006, masih terdapat kesalahan kebahasaan, gambar, dan konsep, dan dua modul litosfer yang diperoleh dari internet. Penelitian dan pengembangan model konseptual ini menggunakan Model Dick \& Carey (2001) yang dimodifikasi atau disederhanakan. 
Namun, substansi prosedur pengembangan produknya tetap berlaku. Penyederhanaan tersebut dilakukan karena beberapa faktor, antara lain: keterbatasan tenaga, waktu, dan dana.

Jelasnya produk yang akan disusun ditujukan untuk menghasilkan materi litosfer dan pedosfer yang memenuhi standar isi/materi, kebahasaan, dan penyajian dengan memperhatikan hakikat keilmuan geografi untuk SMA/MA kelas X semester II pada standar kompetensi menganalisis unsur-unsur geosfer dan kompetensi dasar menganalisis litosfer dan dampaknya terhadap kehidupan di muka bumi di SMA Negeri 1 Lembar Kabupaten Lombok Barat Nusa Tenggara Barat. Dengan demikian, terdapat lima tahap dari sepuluh tahapan pengembangan Model Dick \& Carey yang tidak dimasukan dalam tahap pengembangan modul ini. Artinya, hanya lima tahap yang dilalui. Dari kelima tahap tersebut, pengembang akan secara serius menyiapkan produk dengan tetap memperhatikan kualitas hasil secara profesional.

Produk modul akan diuji tingkat validitas dan kelayakannya melalui dua tahap, yakni validitas ahli (ahli isi/materi, ahli rancangan buku/bahan ajar, dan ahli bahasa) dan uji coba lapangan. Kelayakan modul diketahui melalui hasil validasi ahli dan angket tanggapan siswa. Subjek uji coba produk penelitian pengembangan ini terdiri atas satu kelas penuh dengan jumlah yang sesuai dengan keadaan siswa di tempat uji coba lapangan dilakukan. Kelas yang dijadikan sebagai sasaran uji coba adalah kelas yang siswanya bukan unggulan dan juga bukan kelas yang dikhususkan. Karakateristik siswanya harus beragam (terdapat keseimbangan gender dan level kepintaran yang beragam). Pada tahap ini, subjek uji coba melibatkan seluruh siswa dalam satu kelas X di SMA.

Seluruh data yang diperoleh dikelompokkan menjadi dua, yaitu data kualitatif dan data kuantitatif. Data kualitatif diperoleh dari hasil validasi ahli isi/bidang studi, dan ahli desain pembelajaran. Data kuantitatif diperoleh berdasarkan skor pertanyaan tersruktur dan skor perolehan terhadap soal/tes setiap kegiatan pembelajaran dari siswa pada saat uji coba lapangan dilaksanakan.

Teknik analisis data yang digunakan untuk mengolah data yang dihimpun dari hasil uji coba lapangan yaitu dengan menggunakan analisis statistik deskriptif. Analisis statistik yang digunakan dalam bentuk analisis persentase. Teknik persentase digunakan untuk mengolah data yang merupakan frekuensi atas tanggapan subjek uji coba lapangan terhadap produk modul. Bentuk persentase dari masing-masing jawaban subjek diolah dengan rumus berikut ini.

$$
\text { Persentase }-\frac{\mathbf{r}}{\mathbf{N}} \times 100 \%
$$

Keterangan: $\quad F=$ jumlah persentase keseluruhan subjek

$$
\mathrm{N} \text { = banyak subjek }
$$

Teknik analisis statistik juga digunakan untuk mengolah data yang diperoleh dari nilai soal/tes penguasaan materi/isi modul yang diberikan kepada siswa. Teknik analisis yang digunakan adalah menggunakan rata-rata hitung, dengan rumus berikut.

$$
\bar{x}=\frac{x 1+x 2+\cdots+x n}{n}
$$

\section{Hasil Penelitian dan Pembahasan}

Produk pengembangan hasil modifikasi Dick \& Carey yang dihasilkan pada penelitian ini ada dua yaitu Modul Litosfer untuk siswa SMA/MA kelas X dan Buku Panduan untuk Guru. Penyusunan materi modul dan buku panduan guru Berdasarkan kurikulum Tingkat 
Satuan Pendidikan (KTSP) 2006 dan BSNP. Produk hasil pengembangan yang diujicobakan adalah Modul Litosfer. Subyek ujicoba lapangan sebanyak 35 siswa kelas X5 SMA Negeri 1 Lembar Kabupaten Lombok Barat. Dasar pemilihan subjek uji coba adalah hasil diskusi dan arahan dari Guru mata pelajaran Geografi SMA Negeri 1 Lembar yang menyatakan bahwa siswa kelas X5 siswanya bukan termasuk anggota kelas unggulan dan juga bukan kelas yang dikhususkan. Karakteristik siswanya juga beragam, terdapat keseimbangan gender dan siswa dengan level kepintaran yang beragam. Harapan peneliti dengan kemampuan yang dimiliki siswa tersebut dapat diperoleh hasil penelitian yang beragam pula tentang tanggapan siswa terhadap isi materi teks, mengidentifikasi masalah-massalah dalam memahami modul, dan perolehan data tingkat pemahaman terhadap penguasaan materi yang disajikan dalam modul.

Produk pengembangan yang dihasilkan pada penelitian ini ada dua yaitu Modul Litosfer untuk siswa yang terdiri dari lima modul antara lain modul 1 Struktur lapisan kulit bumi, Modul 2 Tenaga Endogen, modul 3 Tenaga Eksogen, Modul 4 Pedosfer, dan Modul 5 Erosi Tanah, dan Modul untuk Peganggan Guru yang disusun berdasarkan modifikasi Dick \& Carey. Isi modul pada umumnya berupa pertanyaan-pertanyaan yang membimbing siswa untuk menemukan konsep/ prinsip,kemudian menjadikanya sebagai inti/ kesimpulan dari kegiatan belajar dan menjadikan siswa mampu belajar secara mandiri dan tidak tergantung pada pihak lain (Self Instruction), memberikan kesempatan kepada siswa untuk mempelajari materi pembelajaran secara tuntas karena materi belajar dikemas kedalam satu kesatuan yang utuh ( Self Contained) dan memiliki daya adaptasi yang tinggi (Adaptif), dan bersahabat (User friendly). Berikut ini akan diuraikan deskripsi masing-masing produk hasil pengembangan.

\section{Sistematika Modul Untuk Siswa.}

Produk hasil pengembangan berupa modul yang dapat digunakan sebagai bahan ajar untuk materi Litosfer sebaiknya dipilih struktur atau kerangka yang sederhana dan paling sesuai dengan kebutuhan dan kondisi yang ada.

\section{Pra Pendahuluan}

Kerangka modul tersusun meliputi, Halaman Depan (Cover), Kata Pengantar,Daptar Isi, Peta Konsep, Glosarium, Bagan Kegiatan Belajar, Petunjuk Penggunaaan Modul, Uraian Materi, Rangkuman, Evaluasi,Lembar jawaban, Daptar Pustaka, Kunci Jawaban.

- Halaman depan (cover). Berisi judul modul, untuk siapa modul diperuntukkan, kurikulum yang digunakan, gambar yang mendukung jenis modul, nama penyusun, nama dosen pembimbing, nama dan logo instansi penyusun.

- Kata Pengantar. Berisi serangkaian kalimat dari penyusun tentang gambaran umum isi modul, harapan penyusunan modul, ucapan terima kasih kepada semua pihak yang membantu pengembangan modul, dan permintaan saran dan kritik dari penyusun kepada seluruh pembaca untuk penyempurnaan modul yang dikembangkan.

- Daptar isi. Berisi memuat kerangka (outline) modul yang dilengkapi dengan nomor halaman bagian-bagian isi modul.

- Peta Konsep. Diagram yang menunjukkan kedudukan modul dalam keseluruhan program pembelajaran (sesuai dengan diagram pencapaian kompetensi yang termuat dalam KTSP).

- Glosarium. Memuat penjelasan tentang arti dari setiap istilah, kata-kata sulit dan asing yang digunakan dan disusun menurut urutan abjat (alphabetis). 
- Petunjuk Penggunaan Modul. Bagian ini memuat panduan tata cara menggunakan modul, yaitu sebagai berikut: langkah-langkah yang harus dilakukan untuk mempelajari modul secara benar, dan Perlengkapan seperti sarana/ prasarana/fasilitas yang harus dipersiapkan sesuai dengan kebutuhan belajar.

- Uraian Materi. Bagian ini berisi uraian pengetahuan / konsep/ prinsip tentang kompetensi yang sedang dipelajari.

- Rangkuman. Berisi ringkasan/ konsep/ prinsip yang terdapat pada uraian materi.

- Evaluasi. Bagian ini berisi tes tertulis sebagai bahan pengecekan bagi siswa dan guru untuk mengetahui tingkat penguasaan hasil belajar yang telah dicapai siswa sebagai dasar untuk melaksanakan kegiatan berikutnya

- Lembar Jawaban. Bagian ini merupakan lembar kerja siswa terhadap soal dalam modul.

- Daptar Pustaka. Bagian ini berisi semua refrensi/ pustaka yang digunakan sebagai acuan pada saat penyusunan modul

- Kunci Jawaban. Bagian ini berisi jawaban pertanyaan dari tes yang diberikan pada setiap kegiatan pembelajaran dan evaluasi pencapaian kompetensi. Bagian ini dilengkapi dengan kriteria penilaian pada setiap item tes.

\section{2) Pendahuluan}

Bagian Pendahuluan berisi judul kegiatan belajar, sub-sub kegiatan belajar, Standar kompetensi dan kompetensi dasar, bagian pendahuluan ini terletak diawal masing-masing kegiatan belajar. Bagian tersebut diberikan agar siswa dapat mengetahui tujuan pembelajaran.

\section{3) Kegiatan Belajar}

Materi dalam modul Litosfer terbagi menjadi lima modul yaitu Modul 1 (Struktur Lapisan Kulit bumi), Modul 2 ( Tenaga Endogen), Modul 3 (Tenaga Eksogen), Modul 4 (Pedosfer), modul 5 (Erosi Tanah). Proses kegiatan belajar digunakan dengan pengembangan modul litosfer dengan model Dick \& Caery. Siswa melakukan aktivitas kegiatan belajar mengajar dengan modul Litosfer, dan diharapkan siswa mampu menjawab soal-soal yang ada dalam modul. Siswa tetap dilatih untuk bias belajar mandiri dan percaya pada kemampuannya sendiri. Apabila siswa kurang jelas dengan materi atau tata cara penggunaan modul maka siswa diberi kesempatan untuk bertanya kepada guru sehingga siswa menjadi lebih jelas. Pada akhir proses pembelajaran berlangsung siswa bias langsung mengetahui hasil yang diperolehnya dengan menghitung jumlah skor jawaban yang sesuai dengan rumus yang sudah ada didalam modul.

\section{4) Evaluasi}

Evaluasi yang dimaksud yaitu yang terdapat pada bagian akhir kegiatan belajar, yaitu soal-soal Essay yang tertera pada modul untuk menguji kemampuan dalam penguasaan, dan pemahaman siswa terhadap materi dalam menguasai materi modul. Setelah mengerjakan soal evaluasi siswa dapat mengetahui tingkat keberhasilan belajarnyadengan menghitung sendiri sesuai rumus yang ada pada modul. Apabila nilai siswa mencapai nilai $80 \%$ atau lebih, berarti siswa dapat melanjutkan proses belajar ke modul berikutnya dan apabila siswa memperoleh nilai kurang dari $80 \%$ itu berarti siswa tersebut tidak dapat melanjutkan proses pembelajaran ke modul berikutnya. 


\section{Sistimatika Buku Panduan Guru}

Buku Panduan Guru ini dapat digunakan sebagai penuntun guru dalam mengajar materi Litosfer yang menggunakan Pengembangan modul Litosfer. Buku Panduan guru yang dikembangkan terdiri dari beberapa bagian, yaitu pendahuluan, Buku panduan guru yang berisi modul Litosfer untuk siswa beserta kunci jawabanya.

\section{1) Pendahuluan}

Bagian Pra Pendahuluan dalam modul ini meliputi halaman depan (cover), daftar isi, kata pengantar, identitas mata pelajaran, petunjuk penggunaan modul, panduan pembelajaran dengan modul untuk guru, panduan pembelajaran modul untuk siswa, bagan kegiatan belajar, deskrifsi standar kompetensi dan kompetensi dasar dalam semester genap, kerangka isi mata pelajaran geografi, kerangka isi, instrument evaluasi belajar, perhitungan alokasi waktu, Rpp, Silabus.

RPP dalam buku panduan guru berisi rencana yang menggambarkan prosedur dan pengorganisasian pembelajaran untuk mencapai satu kompetensidasar yang ditetapkan dalam standar isi dan dijabarkan dalam silabus untuk satu kali pertemuan atau lebih. RPP memuat tujuan pembelajaran, metode pengajaran, sumber belajar dan penilaian hasil belajar.

Silabus dalam buku panduan guru ini berisi rencana pembelajaran litosfer, yang mencangkup standar kompetensi dasar, Kompetensi dasar, materi pokok, kegiatan pembelajaran, indicator, penilaian, alokasi waktu, dan sumber/ bahan/ alat belajar.

\section{2) Buku Guru}

Tidak jauh berbeda dengan modul untuk siswa, hanya saja bagian ini memuat RPP dan Silabus disamping itu Buku panduan guru lebih detail dan terinsi sehingga mempermudah guru dalam mengarahkan siswa untuk belajar modul lebih mandiri.

Kunci jawaban pada setiap modul yang ada pada buku panduan guru, dalam hal ini uji kompetensi terdapat dalam buku panduan guru yang dapat diberikan oleh guru hanya kepada siswa yang telah mengerjakan dan menyelesaikan soal-soal evaluasi. Dengan adanya kunci jawaban tersebut diharapkan guru dapat mengarahkan siswa untuk mengetahui tingkat keberhasilan belajarnya dan tingkat penguasaanya belajarnya mempergunakan modul.

\section{Pengolahan Data Uji Coba}

Pengolahan data dari masing-masing instrument dapat dijelaskan sebagai berikut.

\section{1) Format Penilaian Modul (Pertanyaan Terstruktur)}

a) Komentar siswa tentang isi modul.

Semua jawaban siswa menanggapai "Positif" terhadap pertanyaan terstruktur. Tanggapan siswa terhadap modul Litosfer hasil pengembangan dapat disimpulkan demikian: (1) bahwa isi modul sangat lengkap karena setiap sub pokok bahasan dibahas secara mendetail, tertata rapi dan sistematis, (2) peta konsep di dalam modul ini sudah memberikan arahan yang jelas terhadap konsep-konsep penting yang berkaitan dengan materi yang diajarkan, (3) glosarium di dalam modul ini sudah menjelaskan arti dari kata-kata yang tercetak miring dalam modul, (4) bagan kegiatan belajar di dalam modul sudah memberikan arahan yang jelas terhadap prosedur atau langkah-langkah mempelajari modul, (5) indikator di dalam modul sudah memberikan arahan yang jelas terhadap kecakapan yang diharapkan setelah siswa menerima materi pembelajaran, (6) tujuan pembelajaran didalam modul sudah memuat tujuan yang jelas terhadap pencapaian indikator, (7) deskripsi didalam modul sudah memberikan arahan yang jelas terhadap pokok-pokok materi yang akan dibahas, (8) alokasi waktu di dalam modul sudah memberikan arahan terhadap waktu dibutuhkan untuk mempelajari modul, (9) Prasyarat di dalam modul sudah memberikan arahan terhadap 
prasyarat awal yang dibutuhkan siswa untuk mempelajari modul, (10) petunjuk penggunaan modul sudah memberikan arahan terhadap sejumlah langkah yang siswa perlukan untuk mempelajari modul.

Tanggapan siswa selanjutnya sebagai berikut: (11) tes sambil jalan (embedded tes) membantu siswa untuk mengingat materi sebelumnya, (12) penggunaan contoh atau gambar dapat memperjelas pemahaman tentang isi materi, (13) modul pembelajaran ini mampu memudahkan siswa untuk menemukan konsep-konsep dalam geografi, (14) siswa sangat tertarik untuk mempelajari modul, (15) materi yang disajikan dalam modul mudah di pahami, (16) uraian materi dalam modul tidak terlalu sulit, (17) bahasa yang digunakan mudah dipahami, (18) soal-soal yang diberikan di dalam modul ini sudah sesuai dengan uraian materi, (19) lembar jawaban yang disediakan didalam modul membantu memudahkan siswa mengerjakan soal latihan, (20) kunci jawaban didalam modul membantu siswa mencocokkan jawaban soal-soal yang siswa kerjakan, (21) daftar pustaka di dalam modul ini membantu siswa menemukan sumber referensi (bacaan) untuk memperkaya pemahaman materi, (22) modul pembelajaran ini berbeda dibanding dengan modul pembelajaran yang lain yang pernah siswa baca atau dengan buku teks Geografi SMA dengan tofik Litosfer karena isi modul ini lengkap dan sangat menarik.

Penilaian terhadap produk hasil pengembangan dilakukan oleh seluruh siswa yang menjadi subjek uji coba. Penilaian dilakukan berdasarkan hasil perhitungan persentase jawaban siswa yang menjadi subjek uji coba terhadap Modul Litosfer hasil pengembangan. Seluruh siswa menyatakan bahwa modul Litosfer hasil pengembangan sudah baik dan tidak perlu ada perbaikan lagi.

b) Temuan Kesalahan Penulisan

Berdasarkan format penilaian uji coba lapangan, terdapat 4 siswa $(11,43 \%)$ menemukan adanya kesalahan penulisan dalam modul Litosfer hasil pengembangan. Kesalahan penulisan ditujukan pada tabel berikut.

Tabel 1. Kesalahan Penulisan

\begin{tabular}{|c|c|c|c|}
\hline Bagian & $\begin{array}{l}\text { Kesalahan } \\
\text { Penulisan }\end{array}$ & Seharusnya & $\begin{array}{c}\text { Keterangan } \\
\text { (Halaman) }\end{array}$ \\
\hline $\begin{array}{l}\text { - Modul } 1 \text { (Ciri-Ciri Lapisan Litosfer } \\
\text { - Modul } 1 \text { (Batuan Sedimen } \\
\text { - Organik) } \\
\text { - Modul } 1 \text { (Kunci Jawaban nomor 3) } \\
\text { - Modul } 5 \text { (Dampak kerusakan tanah } \\
\text { terhadap kehidupan manusia) }\end{array}$ & $\begin{array}{ll}\text { - } & \text { Alumunium } \\
\text { - } & \text { Tertendapka } \\
& \mathrm{n} \\
\text { - } & \text { Alumunium } \\
\text { - } & \text { Berjangkar }\end{array}$ & $\begin{array}{ll}\text { - } & \text { Aluminium } \\
\text { - } & \text { Terendapka } \\
& \mathrm{n} \\
\text { - } & \text { Aluminium } \\
\text { - } & \text { Berjangka }\end{array}$ & $\begin{array}{ll}\text { - } & 6 \\
\text { - } & 13 \\
\text { - } & 21 \\
\text { - } & 4\end{array}$ \\
\hline
\end{tabular}

c) Materi modul yang sulit Dipahami

Berdasarkan format penilaian uji coba lapangan, terdapat 4 siswa(11,43\%) memberikan komentar terhadap materi modul yang sulit dipahami. Komentar mereka disajikan dalam table berikut.

Tabel 2. Materi Modul yang Sulit Dipahami

\begin{tabular}{lll}
\hline Bagian & Materi Modul yang Sulit Dipahami & Halaman \\
\hline$\bullet$ Modul 2 & $\bullet$ Gambar 2.8 Tipe gunung berapi & $\bullet 8$ \\
& $\bullet$ Gambar 2.6 Jenis gunung berapi berdasarkan & $\bullet 6$ \\
& bentuk dan proses terjadinya & $\bullet 3-5$ \\
\hline
\end{tabular}


d) Kemudahan dan kelebihan modul

Subjek uji coba lapangan mengemukakan beberapa kemudahan dan kelebihan Modul Litosfer hasil pengembangan. Jawaban siswa terhadap kemudahan dan kelebihan modul sangat bervariasi, dapat dijelaskan sebagai berikut: (a) 25 siswa $(71,43 \%)$ menyatakan materi modul lengkap, mudah dan cepat dipahami, (b) 4 siswa $(11,43 \%)$ menyatakan gambarnya menarik dan sesuai dengan materi, (c) 4 siswa $(11,43 \%)$ menyatakan kunci jawaban modul sangat membantu siswa mencocokkan jawaban, (d) 5 siswa (14,29\%)menyataka modul lengkap, (e) 10 siswa $(28,57 \%)$ menyatakan Glosarium dan pete konsep menarik dan sangat membantu memahami materi, (f) 5 siswa(14,29\%) menyatakn daftar isi modul jelas dan membantu, (g) 8 siswa $(22,86 \%)$ menyatakan soal dan kunci jawaban sangat membantu, (h) 6 siswa $(14,29 \%)$ menyatakan sistematika modul rafi dan berurutan, (i) 4 siswa $(11,43 \%)$ menyatakan dapat memeriksa sendiri jawaban latihan, (j) 3 siswa $(8,57 \%)$ menyatakan modul dapat melatih kejujuran, (k) 3 siswa $(8,57 \%)$ menyatakan soal-soal dalam modul relefan dengan dengan uraian materi, (l) 5 siswa (14,29\%) menyatakan belajar dengan modul seperti menjadi seorang guru, (m) 5 siswa (14,29\%) menyatakan tulisan dan bahasa yang digunakan rafi dan mudah dipahami, (n) 4 siswa $(11,43 \%)$ menyatakan daftar pustaka modul sangat membantu mencari dan menelusuri sumber refrensi, (o) 5 siswa $(14,29 \%)$ menyatakan peta konsep modul sangat membantu memahami pokok-pokok materi, (p) 2 siswa $(5,71 \%)$ menyatakan lembar jawaban yang disediakan sangat membantu siswa mengerjakan soal-soal latihan, (q) 2 siswa $(5,71 \%)$ menyatakan petunjuk penggunaan modul sangat membantu siswa memahami cara belajar menggunakan modul. Persentase jawaban siswa terhadap kemudahan dan kelebihan modul.

e) Kesulitan dan Kelemahan modul

Subjek uji coba lapangan mengemukakan beberapa kesulitan dan kelemahan modul Litosfer hasil pengembangan. Jawaban siswa terhadap kesulitan dan kelemahan bervariasi, dapat dijelaskan sebagai berikut: (a) 26 siswa (74,29\%) menyatakan waktu yang tersedia untuk mempelajari modul kurang, (b) 5 siswa (14,29\%) menyatakan kesulitan menghitung bobot jawaban soal latihan, (c) 3 siswa $(8,57 \%)$ menyatakan kadang-kadang siswa bias menyontek kunci jawaban jika pengawasan guru kurang, (d) 1 siswa $(2,85 \%)$ menyatakan soal yang disajikan tidak rinci. Persentase jawaban siswa terhadap kesulitan dan kelemahan modul.

\section{2) Jawaban Siswa Terhadap Soal Latihan dalam Modul}

Keberhasilan belajar siswa ditentukan pada tingkat penguasaan siswa terhadap materi. Apabila siswa mencapai tingkat penguasaan $80 \%$ atau lebih, berarti siswa telah memahami materi modul. Selanjutnya siswa dapat melanjutkan pembelajaran ke modul berikutnya. Jika masih di bawah $80 \%$ siswa harus mempelajari lagi materi dalam modul, terutama bagian yang belum dikuasai, kemudian kembali mengerjakan soal latihan hingga mencapai tingkat penguasaan $80 \%$ atau lebih. Setelah itu siswa dapat melanjutkan pembelajaran kemodul berikutnya. Sajian data nilai siswa hasil tes (lembar jawaban essay) yang telah dikelompokkan disajikan pada table berikut.

Tabel 3. Pengelompokan Perolehan Nilai Siswa Hasil Tes Essay

\begin{tabular}{lllllllllll}
\hline \multicolumn{1}{c}{ Tingkar } & \multicolumn{2}{c}{ Modul 1 } & \multicolumn{2}{c}{ Modul 2 } & \multicolumn{2}{c}{ Modul 3 } & \multicolumn{2}{c}{ Modul 4 } & \multicolumn{2}{c}{ Modul 5 } \\
\cline { 2 - 15 } Penguasan & F & \multicolumn{1}{c}{$\%$} & F & $\%$ & F & \multicolumn{1}{c}{$\%$} & F & \multicolumn{1}{c}{$\%$} & F & $\%$ \\
\hline $90-100 \%$ & 2 & 71,4 & 22 & 62,8 & 18 & 51,4 & 7 & 20 & 22 & 62,8 \\
$80-89 \%$ & 5 & 3 & 8 & 6 & 13 & 3 & 2 & 62,8 & 10 & 6 \\
$70-79 \%$ & 3 & 8,58 & 2 & 22,8 & 1 & 37,1 & 2 & 6 & 2 & 28,5 \\
\hline
\end{tabular}




\begin{tabular}{lllllllllll}
\hline$<70 \%$ & 5 & 14,2 & 3 & 6 & 3 & 4 & 2 & 5,71 & 1 & 7 \\
& 2 & 8 & & 5,71 & & 2,86 & 4 & 11,4 & & 5,71 \\
& & 5,71 & & 8,57 & & 8,57 & & 3 & & 2,86 \\
\hline Jumlah & 3 & 100 & 35 & 100 & 35 & 100 & 3 & 100 & 35 & 100 \\
& 5 & & & & & & 5 & & & \\
\hline
\end{tabular}

Berdasarkan hasil uji coba produk hasil pengembangan terhadap lembar jawaban modul (tabel 4.3 diatas) diperoleh data sebagai berikut: (1) Modul 1 sebanyak 28 siswa (80\%) dapat mencapai nilai $80 \%$ atau lebih , berarti siswa dapat melanjutkan pembelajaran ke modul 2, sedangkan 7 siswa (20\%) harus mempelajari lagi materi yang belum dikuasai dan melakukan ujian ulangan (remedial), (2) Modul 2 sebanyak 30 siswa (85,71\%)dapat mencapai nilai $80 \%$ atau lebih,berarti siswa dapat melanjutkan pembelajaran ke modul 3, sedangkan 5 siswa $(14,29 \%)$ harus mempelajari lagi materi yang belum dikuasai dan melakukan ujian ulangan (remidial), (3) Modul 3 sebanyak 31 siswa (88,57\%) dapat mencapai nilai $80 \%$ atau lebih, berarti siswa dapat melanjutkan pembelajaran ke modul 4, sedangkan 4 siswa $(11,43 \%)$ harus mempelajari lagi materi yang belum dikuasai dan melakukan ujian ulangan (remedial), (4) Modul 4 sebanyak 29 siswa (82,86\%) dapat mencapai nilai $80 \%$ atau lebih, berarti siswa dapat melanjutkan pembelajaran ke modul 5, sedangkan 6 siswa $(17,14 \%)$ harus mempelajari lagi materi yang belum dikuasai dan melakukan ujian ulangan (remedial), (5) Modul 5 sebanyak 32 siswa (91,43\%) dapat mencapai nilai $80 \%$ atau lebih, berarti siswa dapat melanjutkan pembelajaran ke materi berikutnya, sedangkan 3 siswa $(8,57 \%)$ harus mempelajari lagi materi yang belum dikuasai dan melakukan ujian ulangan (remedial).

Setelah dilakukan ujian ulangan (remedial) terhadap siswa yang belum memenuhi kriteria $80 \%$ atau lebih, diperoleh hasil bahwa semua siswa dapat mengerjakan soal latihan yang diberikan terutama soal-soal yang belum bisa dikerjakan pada latihan pertama sehingga semua siswa memenuhi kriteria ketuntasan belajar dan dapat melanjutkan pembelajaran kemodul berikutnya.

\section{3) Jawaban Siswa terhadap Instrumen Tes}

Instrumen tes pilihan ganda merupakan soal latihan yang diberikan kepada siswa setelah siswa mempelajari modul. Tujuanya adalah untuk mengetahui tingkat keberhasilan belajar siswa terhadap modul yang dipelajarinya. Sajian dan nilai siswa hasil tes (lembar jawaban pilihan ganda) yang telah dikelompokkan disajikan pada tabel berikut.

Tabel 4. Pengelompokan Perolehan Nilai Siswa Hasil Instrumen Tes

\begin{tabular}{|c|c|c|c|c|c|c|c|c|c|c|}
\hline \multirow{2}{*}{$\begin{array}{c}\text { Tingkar } \\
\text { Penguasan }\end{array}$} & \multicolumn{2}{|c|}{ Modul 1} & \multicolumn{2}{|c|}{ Modul 2} & \multicolumn{2}{|c|}{ Modul 3} & \multicolumn{2}{|c|}{ Modul 4} & \multicolumn{2}{|c|}{ Modul 5} \\
\hline & $\mathrm{F}$ & $\%$ & $\mathrm{~F}$ & $\%$ & $\mathrm{~F}$ & $\%$ & $\mathrm{~F}$ & $\%$ & $\mathrm{~F}$ & $\%$ \\
\hline $90-10$ & 1 & 45,7 & 14 & 40 & 15 & 42,8 & 20 & 57,1 & 8 & 22,8 \\
\hline $8-89$ & 6 & 1 & 15 & 42,8 & 15 & 6 & 12 & 4 & 20 & 6 \\
\hline $7-79$ & 1 & 40 & 3 & 6 & 4 & 42,8 & 2 & 34,2 & 3 & 57,1 \\
\hline $6-69$ & 4 & 8,57 & 2 & 8,57 & 1 & 6 & - & 9 & 2 & 4 \\
\hline $5-5,9$ & 3 & 2,86 & 1 & 5,71 & - & 11,4 & 1 & 5,71 & 2 & 8,57 \\
\hline $4-4,9$ & 1 & 2,86 & - & 2,86 & - & 2 & - & $\begin{array}{lll}- & \\
\end{array}$ & - & 5,71 \\
\hline & 1 & - & & - & & 2,86 & & 2,86 & & 5,71 \\
\hline & - & & & & & - & & - & & - \\
\hline Jumlah & 3 & 100 & 35 & 100 & 35 & 100 & 35 & 100 & 35 & 100 \\
\hline & 5 & & & & & & & & & \\
\hline
\end{tabular}


Berdasarkan rata-rata hitung terhadap hasil tes penguasan materi/isi modul yang diberikan kepada siswa (pilihan ganda) diperoleh data rata-rata hasil tes siswa sebagai berikut: (1) Modul 1( $\bar{X}=X 8,58)$, (2) Modul 2 ( $\bar{X}=8,49)$, (3) Modul3 ( $\bar{X}=8,61)$, (4) Modul $(\bar{X}=8,69)$, dan (5) Modul $5(\bar{X}=8,3)$. Dengan demikian dapat disimpulkan bahwa siswa dapat menguasai materi yang disajikan dalam tiap modul yang diuji cobakan. Rekapitulasi Hasil Ulangan Siswa (Pilihan Ganda).

\section{Revisi Produk berdasarkan Hasil Uji Coba}

Berdasarkan temuan-temuan pada uji coba lapangan perlu dilakukan (revisi), sehingga produk yang dihasilkan semankin baik. Berdasarkan Format Penilaian Modul (Pertanyaan Terstruktur) ditemukan kesalahan penulisan pada modul 1 Ciri-ciri lapisan Litosfer pada (halaman 6), dan batuan sedimen organik (halaman 13), dan pada kunci jawaban nomor 3 (halaman 21), dan modul 5 Dampak kerusakan tanah terhadap kehidupan manusia, (halaman 4). Kesalahan penulisan tersebut telah diperbaiki. Materi modul yang sulit dipahami ditemukan pada Modul 2 Gambar 2.8 Tipe gunung berapi (halaman 8), gambar 2.6 jenis gunung berapi berdasarkan bentuk dan proses terjadinya (halaman 6), dan tenaga Endogen (halaman 3-5). Telah diperbaiki. Revisi produk berdasarkan jawaban siswa terhadap soal latihan dalam modul dan jawaban siswa terhadap instrument tes, tidak ada revisi karena siswa hanya melakukan tes saja tanpa ada saran untuk perbaikan.

\section{Produk Pengembangan yang Telah Direvisi}

Setelah modul pembelajaran dengan materi Litosfer ditulis, selanjutnya dinilai dan divalidasi oleh ahli desain dan penyajian, ahli isi/materi dan siswa produk hasil pengembangan yang diujicobakan adalah Modul Litosfer, sedangkan Buku Panduan Guru digunakan sebagai pegangan guru dalam memandu siswa pada pembelajaran dengan modul. Sebelum diujicobakan produk tersebut telah divalidasi oleh ahli desain dan ahli materi. Dari hasil beberapa kali penilaian dan validasi, selanjutnya dilakukan beberapa kali revisi sampai akhirnya produk akhir pengembangan yang berupa Modul Litosfer untuk siswa SMA/MA Kelas X dan Buku Panduan untuk Guru dapat terselesaikan dengan baik. Berdasarkan hasil beberapakali penilaian dan validasi mendapat kriteria " sangat layak" untuk dipergunakan

Berdasarkan hasil uji coba lapangan, modul pembelajaran ini telah berhasil menunjukkan kebermanfaatan yaitu nilai yang diperoleh siswa menunjukkan bahwa pemahaman siswa terhadap konsep Litosfer dapat lebih baik dengan menggunakan modul hasil pengembangan. Kriteria yang digunakan untuk penilaian modul Litosfer ini adalah sesuai dengan kriteria standar penilaian bahan ajar dari BNSP yang secara garis besar meliputi dua bagian, yaitu penilaian kelayakan desain dan penyajian dan kelayakan isi/materi. Modul hasil pengembangan adalah penjabaran dari salah satu kompetensi dasar dalam mata pelajaran Geografi di SMA/MA Kelas X yaitu Litosfer. Didalam modul hasil pengembangan uraian materi disajikan secara lengkap, berurutan dan sistimatis sehingga siswa dapat dengan mudah memahami materi yang disajikan. Ciri khas yang paling utama dari modul ini merupakan modul pembelajaran, artinya modul yang digunakan untuk kegiatan pembelajaran. Oleh karena itu, modul ini dibagi menjadi 5 modul, sesuai kebutuhan pembelajaran yang ada dan masing-masing modul hanya digunakan untuk satu kali kegiatan pembelajaran.

Langkah utama penyajian materi dalam pembelajaran dengan modul ini, yaitu (1) Siswa membaca uraian materi, (2) Siswa mengerjakan soal latihan dalam modul, dan (3) Siswa memeriksa sendiri pekerjaan kemudian mencocokkan dengan kunci jawaban yang 
tersedia di dalam modul. Pada setiap modul, untuk mencapai kompetensi dasar yang ditetapkan maka ditetapkan indikator-indikator belajar yang harus dikuasai siswa. Berdasarkan indikator yang ada, isi materi yang akan dipelajari siswa disusun. Penyusunan materi dilakukan dengan pemikiran yang matang dan dengan menggunakan refrensi-refrensi yang sesuai dari buku-buku yang relevan dengan materi yang diajarkan dalam hal ini Litosfer. Modul Litosfer hasil pengembangan telah memenuhi kelayakan sebagai bahan ajar. Setidaknya, ada dua indikasi yang dapat dijelaskan.

Pertama, Kelayakan desain dan penyajian. Berdasarkan hasil revisi dari komentar dan saran perbaikan dari ahli desain dan penjajian dinyatakan baik oleh siswa, hal ini menunjukkan bahwa modul layak digunakan sebagai bahan ajar. Kedua, Kelayakan materi berdasarkan hasil revisi dari komentar dan saran perbaikan dari ahli Materi dinyatakan baik oleh siswa, hal ini menunjukkan bahwa modul layak digunakan sebagai bahan ajar. Proses belajar dengan menggunakan modul hasil pengembangan memiliki kelebihan, yaitu (1) siswa dapat lebih mengoptimalkan kemampuan pemahaman materi karena materi yang disajikan legkap, berurutan dan mudah dipahami, (2) pola atau urutan kegiatan pembelajaran yang runtun dan sistimatis akan membuat siswa lebih terorganisir dan sistimatis dalam memahami materi, (3) siswa memeriksa sendiri jawaban latihan oleh siswa itu sendiri akan menambah rasa percaya diri pada siswa, dan melatih kejujuranya, (4) terlihatnya hasil belajar siswa yang memuaskan dari tes yang diberikan, mengindikasikan bahwa modul hasil pengembangan dapat dijadikan sumber belajar yang baik untuk materi Litosfer. Kekurangan dalam pembelajaran menggunakan modul ini adalah (1) pada awal penggunaan modul, siswa dituntut beradaptasi dengan pendekatan pembelajaran yang disajikan dalam modul sehingga membutuhkan waktu yang agak lama dalam pelaksanaanya, tetapi jika sudah terbiasa waktunya akan lebih cepat, (2) untuk kelas yang besar akan memerlukan pengorganisasian pembelajaran dan pengawasan yang lebih baik oleh guru, karna tanpa pengawasan yang baik hasil pembelajaran tidak akan maksimal. Setelah melalui berbagai langkah dalam pengembangan modul pembelajaran dengan menggunakan model Dick \& Carey, akhirnya diperoleh bentuk akhir modul pembelajaran geografi dengan materi Litosfer untuk siswa SMA kelas X semester 2.

\section{Kesimpulan}

Kesimpulan dari hasil penelitian dan pengembangan yang telah dilakukan yaitu: Pertama, Desain produk dan isi modul pembelajaran Geografi SMA untuk materi Litosfer dengan menggunakan Dick \& Carey, terdiri dari lima modul yakni (1) Modul 1 (Struktur Lapisan Litosfer), (2) Modul 2 (Tenaga Endogen), Modul 3 (Tenaga Eksogen), Modul 4 (Pedosfer), Modul 5 (Erosi Tanah). Kedua, Bentuk self-assessment dalam modul pembelajaran Litosfer ini adalah berupa soal-soal latihan yang bertujuan untuk mengukur tingkat pemahaman siswa terhadap materi yang telah dipelajari. Ketiga, Pembelajaran dengan menggunakan modul Litosfer menekankan pada belajar mandiri, yang menyediakan pengalaman belajar yang self-direct, yaitu para siswa berinteraksi dengan bahan ajar dan mendapat umpan balik langsung mengenai belajar yang telah dilakukan oleh mereka sendiri. Dalam hal ini siswa sendiri yang membimbing dirinya untuk belajar di dalam kelas. Keempat, Modul hasil pengembangan terbukti efektif dalam meningkatkan hasil belajar siswa. Hal ini dapat dilihat dari perolehan nilai hasil tes siswa, baik tes pemahaman materi dalam modul maupun hasil tes yang diberikan di luar modul.

Berdasarkan lembar jawaban siswa pada tes di dalam modul diperoleh hasil rata-rata sebagai berikut: (1) Modul 1 (88,28\%), Modul 2 (87,6\%), Modul 3 (85,43\%), Modul 4 
(82,20\%), Modul 5 (90\%). Ini berarti lebih dari $80 \%$ siswa tuntas belajar dengan menggunakan modul hasil pengembangan. Berdasarkan lembar jawaban siswa pada tes di luar modul diperoleh hasil rata-rata sebagai berikut: (1) Modul $1(8,58)$, Modul $2(8,49)$, Modul 3 (8,61), Modul $4(8,69)$, Modul 5 (83). Ini berarti siswa tuntas belajar dengan menggunakan modul hasil pengembangan.

\section{Saran}

Saran yang dapat disampaikan berdasarkan hasil penelitian ini yaitu agar hasil pengembangan modul ini dapat diterapkan oleh guru-guru mata pelajaran geografi lainnya dengan menggunakan metode pembelajaran yang kreatif.

\section{Daftar Pustaka}

Ardana, I W. dan Willis, V. (2002). Reading in Instruktional Development, Volume One Jakarta: Departemen Pendidikan dan Kebudayaan Direktorat Jenderal Pendidikan Tinggi P2LPTK.

Barab, Sasha A. (2004). Using desigs to advance learning theory, or using learning theory to advance desing. Educationel Technology,44(3): 16-2U.

BSNP. (2006). Petunjuk Teknis Pengembangan Silabus Matapelajaran Geografi SMA. Jakarta: Departemen Pendidikan Nasional.

Cennamo, K.S. \& Kalk, D. (2005). Sistematic and Sistemic Design Of Instruction as an Interactive Process: A Functional Model for Practice in the Real World. Educational Technology, 45 (3): 40-48.

Cuningsworth, Alan, (1995). Choosing Your Course Book. Oxford: Heinemann

Depdiknas. (2006). Pedoman Memilih dan Menyusun Bahan Ajar. Jakarta: Departemen Pendidikan Nasional.

Dick, Walter \& Carey, Lou. (2001). The Sistemetic Design Of Instruction. Mionois: Scott, Foresman and Company.

Erman,S. Ar. (2004). Model-model Pembelajaran Matematika, Bandung: LPMP Jawa Barat.

Ghofur, S. A. (2006). Buku Pelajaran Bermutu. Jawa Pos, hlm. 9.

Gabb, Betsy \& Lee, Yeun Sook. (2009). Development and Evaluation of Interior Desing Studio Teaching Modules. Home Economics Research Journal, Volume 14, Issue I.

Hernowo. (2005). Menjadi Guru yang Mau dan Mampu Membuat Buku: Buku Pengayaan untuk Guru. Bandung: MLC.

Husein, M. (2003). Pengembangan Paket Pembelajaran Dasar Listrik dan Elektro Model Walter Dick dan Lou Carey pada SMK Muhammadiyah I Malang. Tesis tidak diterbitkan. Malang: PPs UM.

Hamzah, Syukri. (2007). Pengembangan Model Buku teks Pendidikan Lingkungan Hidup Berbasis Lokal dalam mata pelajaran Ilmu Pengetahuan Sosial Pada Satuan Pendidikan Sekolah Dasar, (Online), ( http://www.mejapaksyukri.com, diakses 23 Maret 2009)

Junaidi. (2008). Pengembangan Paket Pembelajaran Matapelajaran Sains Kelas V Sekolah Dasar Menggunakan Model Dick \& Carey. Tesis tidak diterbitkan. Malang: PPs UM.

Kang, Shumin. (2004). Instructional Design and Development: A Brief Historical Overview. Educational Technology, 44 (6): 39-45.

Lase, Arwita Dinar Sari. (2010). Pengembangan Modul Pembelajaran Kimia Dengan Pendekatan Inquiri Terbimbing Pada materi Termokimia untuk siswa kelas XI IPA. Tesis, Jurusan Pendidikan Kimia, Program Pascasarjana Universitas negeri Malang. 
Miarso, Yusufhadi. (2004). Menyemai Benih Teknologi Pendidikan. Jakarta: Prenada Media.

Merrill, M, David (2004). The Science of Instruction and the Technology of Instructional desing, Educational Technology, 44 (3): 45-46.

Purwanto, E. \& Sumarmi. (1999). Pencitraan Bahan Ajar IPS-Geografi SLTP yang Disusun Berdasarkan Kurikulum 2004. Forum Penelitian Kependidikan, 12 (2): 181-192.

Purwanto, Edy dan Sumarmi. (2001). Pencitraan Buku Teks Geografi SMU Berdasarkan Kurikulum 1994. Malang: Lemlit Universitas Negeri Malang.

Reigeluth, C, M. (1999). Instructional Desingn Theories and Models: A New Paradigma of Instructional Theory. Volume II. New Jersey: Lawrence Erlbraum Associates Publishers.

Sudrajat, Akhmad. (2008). Sumber Belajar Untuk Mengefektifkan Pembelajaran Siswa, (Online), (http://www.akhmadsudrajat.com), diakses 24 April 2010.

Sudrajat, Akhmad. (2010). Pengembangan Bahan Ajar, (Online), (http://akhmadsudrajat.wordpress. com/ Pengembangan Bahan Ajar), diakses, 14 April 2010.

Sudrajat, Akhmad. (2008). Pengembangan Buku Teks. (Online), (http://www.akhmadsudrajat.com), diakses 24 April 2010.

Sugiyono. (2008). Metode Penelitian Kuantitatif, Kualitatis dan R\&D. Bandung: Alfabeta.ssss

Sumarmi, dkk. (2001). Pencitraan Buku Teks Geografi SMU Berdasarkan Kurikulum 1994. Malang: Lemlit Universitas Negeri Malang.

Suparman, A. (1997). Desain Instruksional. Jakarta: Direktorat Pendidikan Tinggi, Departemen Pendidikan dan Kebudayaan.

Sutama. (2006). Modul Litosfer, (Online), (http//www.jevuska.com.), diakses 5 Oktober 2010.

Suyanto, dkk. (2000). Keefektifan Penggunaan Buku Pelajaran SLTP. Malang: Lemlit Universitas Negeri Malang. 